\title{
EXPRESSION OF CD44 AND IDH1 R132H IN GLIOMAS AND THEIR PROGNOSTIC RELEVANCE
}

\author{
Arvīds Jakovlevs ${ }^{1, \#}$, Andrejs Vanags ${ }^{2}$, Jānis Gardovskis ${ }^{2}$, and Ilze Štrumfa ${ }^{1}$ \\ ${ }^{1}$ Department of Pathology, Rīga Stradiṇš University, 9a Kuldīgas Str., Rīga, LV-1007, LATVIA \\ ${ }^{2}$ Department of Surgery, Rīga Stradinš University, 13 Pilsoṇu Str., Rīga, LV-1002, LATVIA \\ \# Corresponding author, arvids.jakovlevs@rsu.Iv
}

Contributed by Jānis Gardovskis

\begin{abstract}
Gliomas are among the most common and aggressive primary brain tumours with dismal prognosis. A lot of research has been directed towards elucidating the molecular basis of these tumours, but few reliable prognostic markers are known. It is necessary to continue to study possible molecular factors that may be involved in development of gliomas or have a prognostic role. CD44 is a marker of neural stem cells and is involved in invasiveness of different tumours. In addition, IDH1 R132H mutant protein is expressed in secondary glioblastomas (GBMs) with much better prognosis. The goal of this study was to evaluate the expression and prognostic role of CD44 and IDH1 R132H in gliomas by immunohistochemistry. In this study, we found that CD44 expression was more prominent in glioblastomas than diffuse astrocytomas and it was not correlated with IDH1 mutational status. CD44 was not found to have a prognostic role in gliomas, in contrast with IDH1 R132H positive status, which was associated with better prognosis. Interestingly, higher CD44 expression values were associated with smaller size of GBMs and female gender indicating that the glioma stem cell population may be altered by gender specific factors and the growth rate of the tumour.
\end{abstract}

Key words: astrocytoma, glioblastoma, immunohistochemistry, survival, molecular subtypes.

\section{INTRODUCTION}

Gliomas are among the most aggressive human cancers and despite recent advances in multimodal treatment, high-grade glioma remains fatal. Although clinical and morphological features and their prognostic impact on glioma patients have been widely described by various authors, nowadays all attention is focused on understanding and evaluation of molecular prognostic factors. A lot of research has been directed towards elucidating the molecular and genetic basis of these tumours, but few reliable prognostic markers have been described. Proteins involved in hallmark biological features of neoplasms, such as proliferation, invasion, and renewal from stem cells, are the best candidates for research as possible potential therapeutic targets.

CD44 is a protein that is involved in a wide range of molecular interactions that determine aggressiveness of different human cancers, including gliomas. CD44 is a transmembrane glycoprotein that serves as a major surface hyaluronic acid receptor and is involved in cell-matrix adhesion, cell migration and various cellular signalling pathways (Naor et al., 1997; Dzwonek et al., 2015). Although CD44 is well known as a molecule involved in adhesion and thus implicated in invasiveness of cancer, it is also known as a tumour stem cell marker for different malignancies including glioblastoma (GBM) (Jijiwa et al., 2011; Sahlberg et al., 2014). Interestingly, CD44 was also described as a marker of mesenchymal differentiation and the so-called mesenchymal molecular subtype of GBM, which is characterised by high transcription levels of several mesenchymal markers such as YLK-40, MET and also CD44 (Phillips et al., 2006; Verhaak et al., 2010; Brown et al., 2015). Regarding the prognostic role of CD44 in gliomas, more evidence suggests that high CD44 is associated with worse prognosis in gliomas (Ranuncolo et al., 2002; Anido et al., 2010; Motomura et al., 2012; Si et al., 2020). However, other researchers have found that the CD44 expression pattern is correlated with poor prognosis only in a small fraction in GBMs with the so-called proneural gene expression signature (Pietras et al., 2014). CD44 also predicts resistance to chemotherapy in the mesenchymal-like glioma subtype 
(Klank et al., 2017). Recently, the CD44 molecule was successfully identified as a molecular target in a mouse model of glioma, indicating its huge potential role in future targeted glioma therapy (Wang et al., 2020). Thus, CD44 seems to be an important prognostic indicator and new studies are necessary to evaluate its biological role.

Isocitrate dehydrogenase (IDH) is a metabolic enzyme having an important role in the citric acid cycle. IDH1 R132H, the most frequent mutation of the IDHI gene in glioma, results in missense replacement of arginine by histidine, leading to production of the mutant enzyme that catalyses the synthesis of oncometabolite 2-hydroxyglutarate (Ward et al., 2012). IDH1 mutations are early events in the development of gliomas, and thus the majority of diffuse astrocytomas (DAs) and secondary GBMs bear this signature (Cohen et al., 2013). Immunohistochemical detection of IDH1 R132H protein is a routine practice nowadays to distinguish between primary and secondary GBMs that have better prognosis. The aim of the study was to evaluate the expression and prognostic role of CD44 and IDH1 R132H status in gliomas.

\section{MATERIALS AND METHODS}

A retrospective study was carried out in compliance with laws and regulations on principles of ethics in accordance with the Declaration of Helsinki. In our study, archived formalin-fixed, paraplast-embedded tissues of $146 \mathrm{GBMs}$, including five secondary GBMs and 26 diffuse astrocytomas (DAs), were analysed by immunohistochemistry (IHC). Anaplastic astrocytomas were excluded from the study, because we evaluated the two most contrasting grades of diffuse gliomas. The cases were identified by an archive search of all consecutive patients (2009-2014) who were subjected to neurosurgical treatment by routine indications in a single university hospital. The diagnosis and grade of the gliomas were verified by two pathologists in accordance to the 2016 WHO classification of tumours of the CNS (Louis et al., 2016). All recurrent tumours and previously treated patients, unacceptably small samples including stereotactic biopsies, and damaged material containing large areas of necrosis or coagulation artefacts $(>50 \%$ of the sample) were excluded from the study. The basic clinical data (e.g., patient's age and gender) as well as information about previous treatment or tumour recurrences were retrieved from medical records. The glioma samples were tested for CD44 and IDH1 R132H. Immunohistochemical visualisation for IDH1 R132H was used for detection of IDH1-mutant glioma cases. For IHC, 3-micrometre-thick sections were cut on electrostatic glass slides (Histobond, Marienfeld, Germany). After deparaffinisation and rehydration, heat-induced antigen retrieval was performed in a microwave oven $(3 \times 5 \mathrm{~min})$ using a basic TEG $(\mathrm{pH} 9.0)$ buffer (Agilent Dako, Santa Clara, United States of America), followed by blocking of endogenous peroxidase (Sigma-Aldrich Ltd., Gillingham, United Kingdom). The sections were incubated with primary antibodies at room temperature. The specimens were incubated with anti-CD44 antibody (monoclonal mouse antibody; clone DF1485; dilution 1:50) and anti-IDH R132H (monoclonal mouse antibody, clone H09; 1:50). Bound primary antibodies were detected by the enzyme-conjugated polymeric visualisation system EnVision (Agilent Dako), linked with horseradish peroxidase using 3,3'-diaminobenzidine (Agilent Dako) as the chromogen. Positive and negative quality controls were invariably performed and reacted appropriately. Expression of markers was evaluated by light microscopy under magnifications of $40 \times$ and $400 \times$, using an Eclipse Ci-L (Nikon, Tokyo, Japan) microscope. By intensity, the expression was evaluated as negative vs. low vs. moderate vs. high intensity. The expression of a marker was considered positive only if the expression intensity was moderate or high. The cytoplasmic or membranous expression of CD44 was evaluated quantitatively as the fraction (\%) of neoplastic cells. The expression of IDH1 R132H mutant protein was evaluated only as positive vs. negative. For survival analysis, expression of CD44 was classified into high and low expression using a cut-off value of 50\% (Popova et al., 2014). Descriptive statistical analysis was performed and included the calculation of $95 \%$ confidence intervals (CI) by CIA software (Altman et al., 2000). Survival was evaluated using Kaplan-Meier analysis. In addition, clinical data such as patient's age, gender and tumour size estimated by magnetic resonance imaging (MRI) were used in statistical analysis using the Mann-Whitney test and Spearman's rank order correlation analysis.

\section{RESULTS}

The study included 146 patients with GBM and 26 patients with DAs diagnosed during the period from 2009-2014 in a single university hospital. GBM was diagnosed in 75/146 (51.4\%; $95 \% \mathrm{CI}=43.3-59.5)$ females and in 71/146 males (48.6\%; 95\% CI $=40.5-56.7)$. The age of the patients ranged from $34-89$. The mean age \pm standard deviation (SD) was $62.0 \pm 11.2(95 \% \mathrm{CI}=60.2-63.8)$. DAs were diagnosed in $14 / 26(53.8 \%$; $95 \% \mathrm{CI}=34.6-72.7)$ females and $12 / 26(46.2 \%$; $95 \% \mathrm{CI}=27.0-65.4)$ males. The age of patients ranged from 21 to 67 . The mean age \pm SD was $37.5 \pm$ 11.2 (95\% CI $=33.0-42.0$ ). In GBM, the greatest tumour diameter measured from MRI series ranged from 1 to $9 \mathrm{~cm}$; mean $\pm \mathrm{SD}$ was $5.1 \pm 1.4(95 \% \mathrm{CI}=4.85-5.36)$. In 101/123 $(29.5 \%$; $95 \% \mathrm{CI}=21.4-37.6)$ of GBM cases the greatest diameter exceeded $4 \mathrm{~cm}$. In 22/123 (15.1\%; 95\% CI = 8.8-21.4) of GBMs the greatest diameter was less than $4 \mathrm{~cm}$. The MRI data were missing for 23/146 (15.7\%; $95 \%$ $\mathrm{CI}=9.8-21.6)$ of the sample. In DAs, the greatest tumour diameter measured from MRI series ranged from 4.7 to $9 \mathrm{~cm}$; mean $\pm \mathrm{SD}$ was $6.1 \pm 0.9(95 \% \mathrm{CI}=5.6-6.7)$. The MRI data and information about the tumour size were missing for $13 / 26(50.0 \%$; 95\% CI $=30.8-69.2)$ of the samples.

CD44 protein was expressed in a significantly greater percentage of cells in GBMs compared with DAs: 74.1\% (95\% $\mathrm{CI}=69.6-78.7)$ versus $13.5 \%(95 \% \mathrm{CI}=7.7-19.2)$. All cases of GBMs and DAs showed CD44 expression, at dif- 
ferent levels. Strong expression of CD44 in more than 50\% of neoplastic cells was found in $81.5 \%$ [95\% CI = 74.6-87.4] of GBM compared with only one DA which reached this level of expression. Intense, diffuse membranous expression was the predominant pattern of CD44 immunoreactivity in GBMs. However, expression of CD44 in DAs was weak and mostly limited to numerous cytoplasmic processes of astrocytes, creating a richly branched, delicate network of low CD44 immunoreactivity. In addition to this weak CD44 expression, all DAs had patchy areas with at least a moderate expression level of CD44.

IDH1 R132H protein expression was found in 3.4\% $(95 \%$ $\mathrm{CI}=0.5-6.3)$ of GBMs compared with $76.9 \%$ (95\% CI = 60.7-93.1) of DAs. All cases showed intense nuclear staining. Among the positive GBMs cases, only one GBM morphologically showed a component of lower grade glioma, thus confirming secondary GBM on morphological grounds. All IDH1 R132H positive GBMs $(n=5)$ lacked any radiological or clinical evidence of a pre-existing lowgrade tumour. The mean age of patients with secondary GBMs (IDH1 R132H positive) was 50.6 (95\% CI = 48.9-52.2) years compared with primary GBMs (IDH1 $\mathrm{R} 132 \mathrm{H}$ negative $)-62.4(95 \% \mathrm{CI}=60.7-64.0)$ years.

A significant association was found between the gender and expression of CD44 protein in GBMs. Thus, significantly higher expression of CD44 was found in females according to the Mann-Whitney test $(\mathrm{z}=-2.224 ; p=0.026)$. CD44 also showed a weak, significant, negative correlation with size of GBM $\left(\mathrm{r}_{\mathrm{s}}=-0.314 ; p<0.0001\right)$. In addition, higher CD44 expression values more frequently were found in GBMs with smaller size $(<4 \mathrm{~cm})$ (Mann-Whitney U test, $\mathrm{z}=-2.364 ; p=0.018$ ). There were no significant differences between CD44 expression by gender or size in DAs. There was no difference between CD44 expression in primary (IDH1 R132H negative) or secondary (IDH1 R132H positive) GBMs. Immunohistochemical visualisation of CD44 expression in GBM and DAs is shown in Figures 1 and 2 .

For GBMs the survival data was available for 135 patients, who had been included in survival analysis. At the end of the study $2 / 135(1.5 \%$; $95 \% \mathrm{CI}=0-5.2)$ patients were alive, but $133 / 135$ (98.5\%; $95 \%$ CI $=94.8-99.6)$ had died during the observation period. The overall median survival time was 7.9 months $(95 \% \mathrm{CI}=6.8-9.0)$. For DAs, the survival data were available for 25 patients who had been included in survival analysis. At the end of the study 14/25 (56.0\%; $95 \% \mathrm{CI}=37.0-73.3)$ patients were alive, but $11 / 25$ (44.0\%; 95\% CI $=26.6-62.9)$ had died during the observation period. Because of the small study group and small number of death cases in the DAs group, statistical calculations were unreliable and the overall median survival time could not be calculated. The survival plot by Kaplan-Meier for GBMs and DAs is shown in Figure 3.

In GBMs, there was a statistically significant difference of overall survival (OS) regarding the patient age (log-rank, $p<0.001)$. Median OS of patients with age $\leq 65$ years old was 11.7 (95\% CI = 8.1-15.3) months, however median OS of patients older than 65 years was $5(95 \% \mathrm{CI}=3.2-6.8)$ months. Thus, younger age at diagnosis is associated with significantly longer survival rate in GBMs patients. There was also a statistically significant difference of median OS regarding the size of tumour (log-rank, $p=0.018$ ). Median
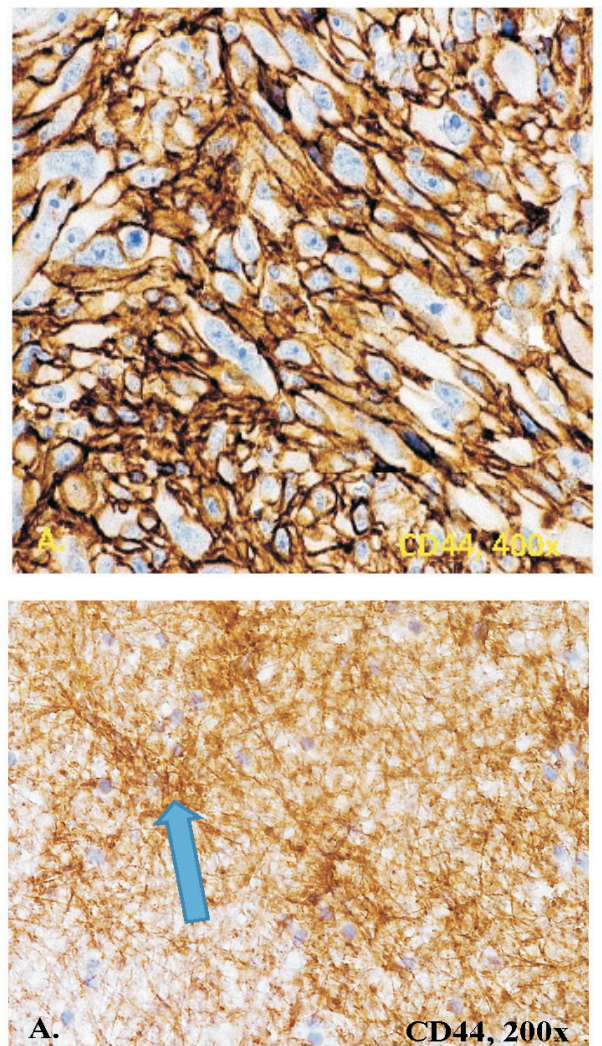
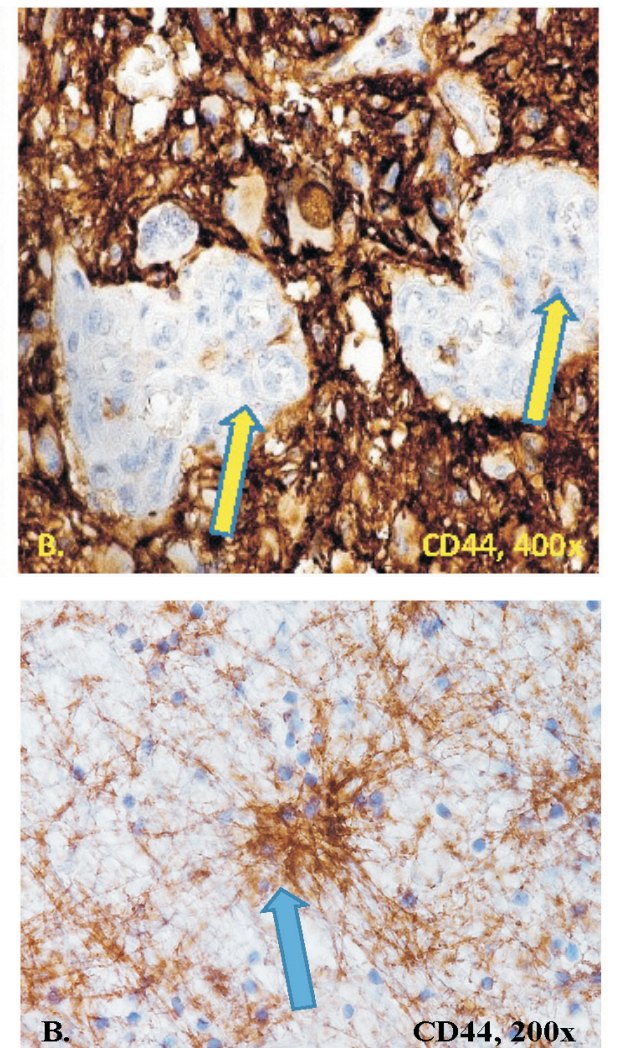

Fig. 1. Intense membranous expression of CD44 in glioblastomas. Note prominent, proliferative blood vessels negative for CD44 (internal negative control) (arrows). Immunoperoxidase, anti-CD44, original magnification $400 \times$.

Fig. 2. Expression of CD44 in DAs. Weak background expression in fibrillary cytoplasmic processes of astrocytes is seen together with foci of higher expression intensity (arrows). Immunoperoxidase, anti-CD44, original magnification $200 x$. 

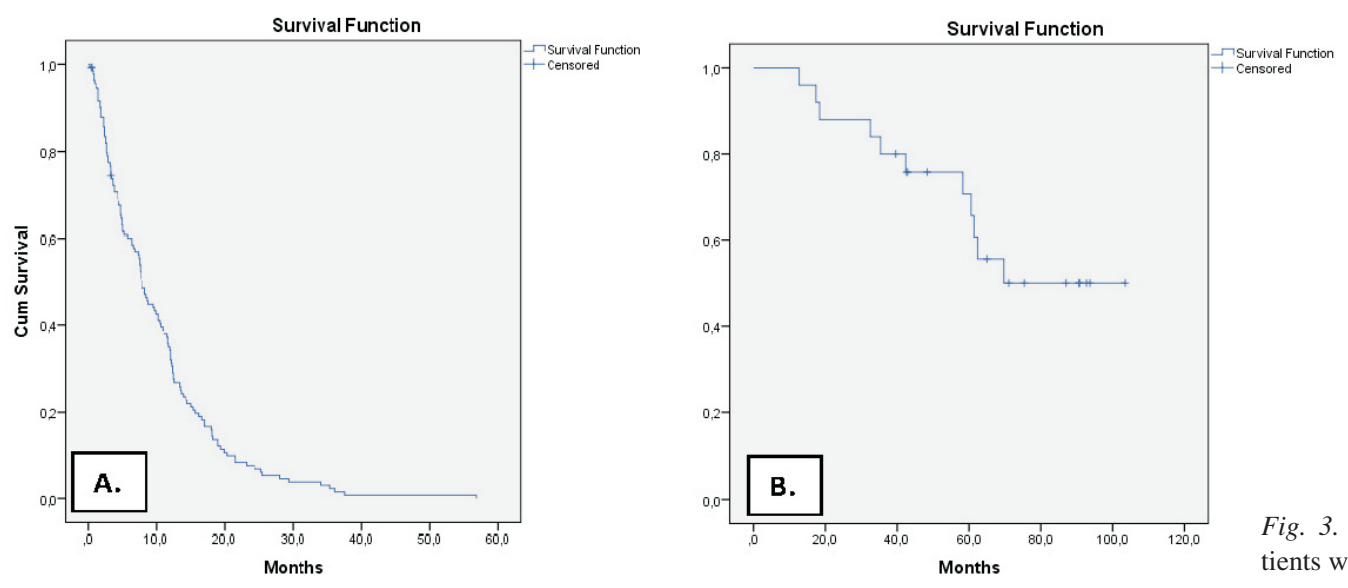

Fig. 3. Kaplan-Meier survival plots of patients with glioblastomas (A) and DAs (B).
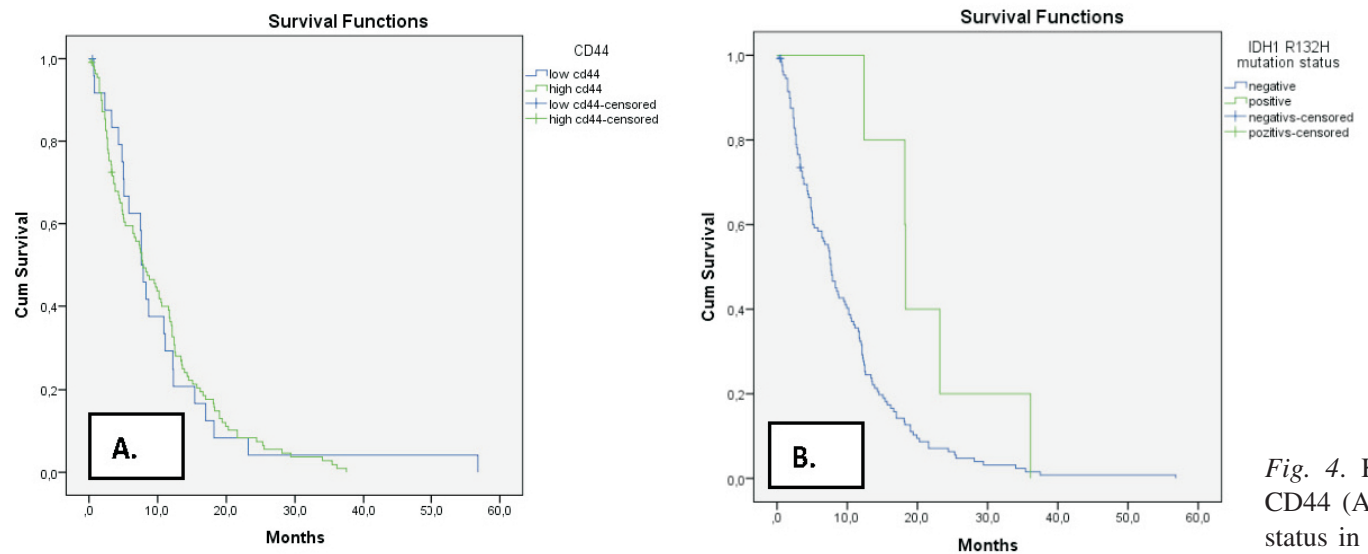

Fig. 4. Kaplan-Meier survival curves by CD44 (A) and IDH1 R132H (B) mutation status in patients with glioblastomas.

OS rates in patients with tumours $\leq 4 \mathrm{~cm}$ and $>4 \mathrm{~cm}$ were, respectively, $11.8(95 \% \mathrm{CI}=8.1-15.5)$ months and 6.8 $(95 \% \mathrm{CI}=4.7-8.8)$ months. There were no survival differences regarding CD44 expression in both GBMs and DAs. In GBMs, a statistically significant survival difference was found in patients regarding IDH1 R132H mutant protein expression (log rank, $p=0.040$ ). Thus, patients with secondary GBMs (IDH1 R132 positive) had a median OS of 18.3 $(95 \% \mathrm{CI}=18.0-18.5)$ months versus $7.7(95 \% \mathrm{CI}=$ 6.3-9.0) months in patients with primary GBMs (IDH1 R132H negative). The corresponding Kaplan-Meier curves are shown in Figure 4.

\section{DISCUSSION}

Diffuse gliomas do not rank among the malignancies with the highest incidence, such as lung cancer, breast cancer or colorectal cancer, but, nevertheless, gliomas rank among the most aggressive human malignancies with limited treatment options. The most common and the most aggressive type of glioma is GBM, so many international studies have focused on this tumour. It is crucial to better understand specific signalling pathways and molecular alterations determining biological features of gliomas, such as invasion, proliferation, and resistance to current therapy, because this is the only way that can bring a ray of hope for improved target specific management, as well as, development of personalised therapy.

CD44 is transmembrane glycoprotein that serves as a major surface hyaluronic acid receptor and is involved in cell- matrix adhesion, cell migration and various cellular signalling pathways (Naor et al., 1997; Dzwonek et al., 2015). Its membranous localisation may be important in facilitation of invasion of neoplastic cells by CD44-hyaluronan interaction (Bradshaw et al., 2016). CD44 engagement with hyaluronan has also been suggested to enhance tumour progression through increased tyrosine kinase activity and resistance to treatment, accentuating this molecular association as a desirable treatment target (Mooney et al., 2016). CD44 has multiple isoforms due to splicing and post-translational modification and is characterised by high functional diversity (Prochazka et al., 2014).

It is also involved in cell adhesion, angiogenesis, lymphocyte activation and cytokine release (Petrey et al., 2014). CD44 was described as a cancer stem cell marker in different tumours, including glioblastoma. In the nervous system CD44 has been identified as a marker of neural stem cells, as well as of astrocyte and oligodendrocytes precursors (Liu et al., 2004; Naruse et al., 2013). Some authors have also noted that, in glioblastoma, CD44 functions as a neural progenitor cell marker being expressed on partially differentiated cells (Bradshaw et al., 2016).

CD44 is involved in mesenchymal transformation of tumour cells and enhances the invasiveness by promoting the adhesion (Xu et al., 2015). In the molecular classification of glioblastoma, CD44 was described as a marker of the mesenchymal subtype (Phillips et al., 2006; Verhaak et al., 2010). The immunohistochemical assessment of CD44 was suggested to become a mainstay in the molecular typing of 
glioblastomas by an economically effective surrogate method, in parallel to the achievements in breast cancer research (Popova et al., 2014). However, significant controversies exist in the literature, as further shown. In this study, CD44 expression strongly depended on tumour grade with the highest expression levels seen in GBMs. The mean expression value of CD44 in GBMs was $74.1 \%(95 \% \mathrm{CI}=$ 69.6-78.7) versus $13.5 \%(95 \% \mathrm{CI}=7.7-19.2)$ in DAs. High CD44 expression (with cut-off of $50 \%$ ) was found in $81.5 \%$ (95\% CI $=74.4-86.9)$ of GBMs, but none of DAs had CD44 expression above this level. In comparison with this study, Popova et al., found high CD44 expression in $42 \%$ if GBMs and $15 \%$ of DAs by using same cut-off point (Popova et al., 2014). However, Ranuncolo et al. (2002) by using a higher cut-off point of $70 \%$, found high CD44 expression in $59 \%$ of GBMs and $9.5 \%$ of low-grade gliomas. Other authors observed similar relationships between glioma grade and CD44 expression (Ranuncolo et al., 2002; Popova et al., 2014). However, some studies found no association between the grade of glioma and CD44 expression (Ylagan et al., 1997). These conflicting findings regarding CD44 expression have unclear reason, but may be caused by the multiple splicing variants of CD44 protein (Prochazka et al., 2014) or improvements in the affinity of primary antibodies or general immunohistochemical technologies. Few studies have specified the CD44 staining pattern in glioma tissues. The most prominent and typical is membranous, surface staining of CD44, and such a staining pattern was intense and observed in all GBMs in this study. However, such membranous staining pattern was identified in few DAs and it was patchy and vague. In contrast, all DAs had faint, barely noticeable CD44 immunoreactivity in cytoplasmic processes of astrocytes, creating a branched, delicate network of CD44 immunopositivity. In this study weak, diffuse CD44 expression was not counted quantitatively and it did not account for assessment of positive cases of DAs, however it should be noted as a different staining pattern in low-grade gliomas. One study described a similar staining pattern in gliomas: membranous staining was found only in GBMs, but weak staining in processes of astrocytes characterised DAs (Jijiwa et al., 2011). Interestingly, different authors described occurrence of CD44 expression within processes of some fibrillary astrocytes in normal human brain (Sosunov et al., 2014). Kaaijk et al., hypothesised that CD44 expression in normal astrocytes might contribute to migratory capacity of astrocytes upon inflammation and other injury (Kaaijk et al., 1997). However, Lui et al., showed that CD44 expression identified astrocyte-restricted precursor cells (Liu et al., 2004). In many other recent studies, CD44 has been also identified as a marker of astrocyte precursor cells (Naruse et al., 2013; Malik et al., 2014). Thus, we suppose that weak background CD44 immunoreactivity in processes may indicate the stemness and precursor state of neoplastic astrocytes in DAs. However, in high-grade gliomas, for achievement of more aggressive behaviour and increased invasive properties of tumour cells, CD44 is significantly upregulated on the surface of neoplastic cells. In addition, the CD44 molecule may play different roles in biology of neoplastic and non-neoplastic brain cells and the function of CD44 might be isoform specific. Regarding the prognostic role of CD44, many authors have shown that high CD44 expression is related to worse prognosis in glioma patients (Ranuncolo et al., 2002; Anido et al., 2010; Motomura et al., 2012). In this study, no prognostic role of CD44 was found in GBMs and DAs. We suppose that the prognostic role of CD44 might be isoform specific and it is important to evaluate the function and prognostic role of different CD44 splicing variants. Interestingly, in this study, in GBMs, CD44 expression was higher in females $(\mathrm{z}=-2.224 ; p=0.026)$, indicating that the glioma stem cell population may be altered by gender specific factors. In addition, CD44 showed a weak, statistically significant, negative correlation with size of GBM $\left(\mathrm{r}_{\mathrm{s}}=-0.314\right.$; $p<0.001)$. This correlation was also confirmed by the association between the size and CD44 expression: higher CD44 expression values more frequently were found in GBMs with smaller size $(>4 \mathrm{~cm})$ than in larger sized tumours $(\geq 4$ cm) $(\mathrm{z}=-2.364 ; p=0.018)$, indicating that expansion and rapid growth of a tumour may lead to depletion of the stem cell population in glioma.

Immunohistochemical detection of IDH1 R132H protein is a routine practice nowadays to distinguish between primary and secondary GBMs that have better prognosis. In the whole group of glioblastomas, secondary GBMs constituted $6-13 \%$ of these tumours (Ohgaki et al., 2013). Significantly lower frequency $(3.4 \%$; $95 \% \mathrm{CI}=0.5-6.3)$ of secondary GBMs was observed in our study, probably due to the study design. In the present investigation, recurrent brain tumours were excluded, as the previous therapy might have been a confounding factor that could affect the molecular characteristics of gliomas (Parsons et al., 2008; Shankar et al., 2014). Thus, all GBMs in our study clinically resembled primary GBMs similarly to Le Mercier et al., 2012 (Le Mercier et al., 2012). A similar group was assessed by Nobusawa et al., who reported very similar frequency of IDH1 gene mutations, namely, $3.7 \%$ of cases clinically presenting as primary GBMs were identified as secondary GBMs by molecular signature (Nobusawa et al., 2009). The frequency of the $I D H 1$ mutation was $3 \%$ in the study of Le Mercier et al., 2012 (Le Mercier et al., 2012). Regarding DAs, expression of mutant IDH1 R132H protein was detected in $76.9 \%$ (95\% CI $=60.7-93.1)$ of tumours, and the remaining $23.1 \%(6.9-39.3)$ were negative for IDH1 $\mathrm{R} 132 \mathrm{H}$ mutation. The frequency of IDHI mutations in low-grade gliomas was $80 \%$ and $87 \%$ (Christensen et al., 2011; Juratli et al., 2012), however, the most frequent specific mutation - IDH1 R132H, was detected by immunohistochemistry in 57-80\% of low-grade gliomas (Popova et al., 2014; Cai et al., 2016), which is also consistent with this study. Presence of the IDHI gene mutation is one of the known prognostic factors of a more favourable prognosis in patients with high-grade gliomas (Parsons et al., 2008; Nobusawa et al., 2009; Gravendeel et al., 2010). For example, median overall survival rates of mutated and nonmutated IDHI patients with GBMs were 3.8 and 1.1 years (Parsons et al., 2008). In this study, patients with secondary GBMs had significantly better prognosis than with primary 
GBMs - median OS was $18.3(95 \% \mathrm{CI}=18.0-18.5)$ months versus 7.7 (95\% CI $=6.3-9.0)$ months $(p=0.040)$. Regarding DAs, patients with IDH1 R132H negative and IDH1 R132H positive tumours did not show statistically significant differences in survival $(p=0.336)$ in this study.

\section{CONCLUSIONS}

1) CD44 expression is significantly more marked in GBMs than in DAs. This finding may point to the importance of CD44 in the development of high-grade gliomas. Also, there were no differences in CD44 expression between primary and secondary GBMs.

2) CD44 expression shows no further prognostic significance within gliomas of the same grade.

3) CD44 expression in GBMs is higher in females, indicating that the glioma stem cell population may be altered by gender specific factors.

4) Higher CD44 expression values more frequently are found in smaller GBMs, indicating that expansion and rapid growth of a tumour may lead to depletion of the stem cell population in glioma.

5) Patients with secondary GBMs had significantly better prognosis than patients with primary GBMs, thus presence of IDH1 R132H mutation was the most significant molecular prognostic factor of better survival.

\section{REFERENCES}

Anido, J., Saez-Borderias, A., Gonzalez-Junca, A., Rodon, L., Folch, G., Carmona, M. A., Prieto-Sanchez, R. M., Barba, I., Martinez-Saez, E., Prudkin, L. et al. (2010). TGF-beta receptor inhibitors target the CD44(high)/Id1(high) glioma-initiating cell population in human glioblastoma. Cancer Cell., 18 (6), 655-668.

Bradshaw, A., Wickremsekera, A., Tan, S. T., Peng, L., Davis, P. F., Itinteang, T. (2016). Cancer stem cell hierarchy in glioblastoma multiforme. Front Surg., 3, 21.

Brown, D. V., Daniel, P. M., D'Abaco, G. M., Gogos, A., Ng, W., Morokoff, A. P., Mantamadiotis, T. (2015). Coexpression analysis of CD133 and CD44 identifies Proneural and Mesenchymal subtypes of glioblastoma multiforme. Oncotarget, 6 (8), 6267-6280.

Cai, J., Zhu, P., Zhang, C., Li, Q., Wang, Z., Li, G., Wang, G., Yang, P., Li, J., Han, B., Jiang, C., Sun, Y., Jiang, T. (2016). Detection of ATRX and IDH1-R132H immunohistochemistry in the progression of 211 paired gliomas. Oncotarget, 7 (13), 16384-16395.

Christensen, B. C., Smith, A. A., Zheng, S., Koestler, D. C., Houseman, E. A., Marsit, C. J., Wiemels, J. L., Nelson, H. H., Karagas, M. R., Wrensch, M. R., Kelsey, K. T., Wiencke, J. K. (2011). DNA methylation, isocitrate dehydrogenase mutation, and survival in glioma. J. Natl. Cancer Inst., 103 (2), 143-153

Cohen, A., Holmen, S., Colman, H. (2013). IDH1 and IDH2 mutations in gliomas. Curr. Neurol. Neurosci. Rep., 13 (5), 345-345.

Dzwonek, J., Wilczynski, G. M. (2015). CD44: Molecular interactions, signaling and functions in the nervous system. Front Cell Neurosci., 9, 175.

Gravendeel, L. A., Kloosterhof, N. K., Bralten, L. B., van Marion, R., Dubbink, H. J., Dinjens, W., Bleeker, F. E., Hoogenraad, C. C., Michiels, E., Kros, J. M., van den Bent, M., Smitt, P. A., French, P. J. (2010). Segregation of non-p.R132H mutations in IDH1 in distinct molecular subtypes of glioma. Hum. Mutat., 31 (3), E1186-1199.
Jijiwa, M., Demir, H., Gupta, S., Leung, C., Joshi, K., Orozco, N., Huang, T., Yildiz, V. O., Shibahara, I., de Jesus, J. A., Yong, W. H., Mischel, P. S., Fernandez, S., Kornblum, H. I., Nakano, I. (2011). CD44v6 regulates growth of brain tumor stem cells partially through the AKT-mediated pathway. PLoS One., 6 (9), e24217.

Juratli, T. A., Kirsch, M., Robel, K., Soucek, S., Geiger, K., von Kummer, R., Schackert, G., Krex, D. (2012). IDH mutations as an early and consistent marker in low-grade astrocytomas WHO grade II and their consecutive secondary high-grade gliomas. J. Neurooncol., 108 (3), 403-410.

Kaaijk, P., Pals, S. T., Morsink, F., Bosch, D. A., Troost, D. (1997). Differential expression of CD44 splice variants in the normal human central nervous system. J. Neuroimmunol., 73 (1-2), 70-76.

Klank, R. L., Decker Grunke, S. A., Bangasser, B. L., Forster, C. L., Price, M. A., Odde, T. J., SantaCruz, K. S., Rosenfeld, S. S., Canoll, P., Turley, E. A., McCarthy, J. B., Ohlfest, J. R., Odde, D. J. (2017). Biphasic dependence of glioma survival and cell migration on CD44 expression level. Cell Rep., 18 (1), 23-31.

Le Mercier, M., Hastir, D., Moles Lopez, X., De Neve, N., Maris, C., Trepant, A. L., Rorive, S., Decaestecker, C., Salmon, I. (2012). A simplified approach for the molecular classification of glioblastomas. PLoS One, 7 (9), e45475.

Liu, Y., Han, S. S., Wu, Y., Tuohy, T. M., Xue, H., Cai, J., Back, S. A., Sherman, L. S., Fischer, I., Rao, M. S. (2004). CD44 expression identifies astrocyte-restricted precursor cells. Dev. Biol., 276 (1), 31-46.

Louis, D. N., Ohgaki, H., Wiestler, O. D., Cavenee, W. K. (2016). Astrocytic tumours. In: WHO Classification of Tumours of the Central Nervous System (Fourth Edition). WHO Press, Lyon, pp. 13-53.

Malik, N., Wang, X., Shah, S., Efthymiou, A. G., Yan, B., Heman-Ackah, S., Zhan, M., Rao, M. (2014). Comparison of the gene expression profiles of human fetal cortical astrocytes with pluripotent stem cell derived neural stem cells identifies human astrocyte markers and signaling pathways and transcription factors active in human astrocytes. PLoS One, 9 (5), e96139.

Mooney, K. L., Choy, W., Sidhu, S., Pelargos, P., Bui, T. T., Voth, B., Barnette, N., Yang, I. (2016). The role of CD44 in glioblastoma multiforme. J.Clin. Neurosci., 34, 1-5.

Motomura, K., Natsume, A., Watanabe, R., Ito, I., Kato, Y., Momota, H., Nishikawa, R., Mishima, K., Nakasu, Y., Abe, T., Namba, H., Nakazato, Y., Tashiro, H., Takeuchi, I., Mori, T., Wakabayashi, T. (2012). Immunohistochemical analysis-based proteomic subclassification of newly diagnosed glioblastomas. Cancer Sci., 103 (10), 1871-1879.

Naor, D., Sionov, R. V., Ish-Shalom, D. (1997). CD44: Structure, function, and association with the malignant process. Adv. Cancer Res., 71, 241-319.

Naruse, M., Shibasaki, K., Yokoyama, S., Kurachi, M., Ishizaki, Y. (2013). Dynamic changes of CD44 expression from progenitors to subpopulations of astrocytes and neurons in developing cerebellum. PLoS One., 8 (1), e53109.

Nobusawa, S., Watanabe, T., Kleihues, P., Ohgaki, H. (2009). IDH1 mutations as molecular signature and predictive factor of secondary glioblastomas. Clin. Cancer Res., 15 (19), 6002-6007.

Ohgaki, H., Kleihues, P. (2013). The definition of primary and secondary glioblastoma. Clin. Cancer Res., 19 (4), 764-772.

Parsons, D. W., Jones, S., Zhang, X., Lin, J. C., Leary, R. J., Angenendt, P., Mankoo, P., Carter, H., Siu, I. M., Gallia, G. L. et al. (2008). An integrated genomic analysis of human glioblastoma multiforme. Science, 321 (5897), 1807-1812.

Petrey, A. C., de la Motte, C. A. (2014). Hyaluronan, a crucial regulator of inflammation. Front Immunol., 5, 101.

Phillips, H. S., Kharbanda, S., Chen, R., Forrest, W. F., Soriano, R. H., Wu, T. D., Misra, A., Nigro, J. M., Colman, H., Soroceanu, L., Williams, P. M., Modrusan, Z., Feuerstein, B. G., Aldape, K. (2006). Molecular subclasses of high-grade glioma predict prognosis, delineate a pattern of disease progression, and resemble stages in neurogenesis. Cancer Cell, 9 (3), $157-173$. 
Pietras, A., Katz, A. M., Ekstrom, E. J., Wee, B., Halliday, J. J., Pitter, K. L., Werbeck, J. L., Amankulor, N. M., Huse, J. T., Holland, E. C. (2014). Osteopontin-CD44 signaling in the glioma perivascular niche enhances cancer stem cell phenotypes and promotes aggressive tumor growth. Cell Stem Cell., 14 (3), 357-369.

Popova, S. N., Bergqvist, M., Dimberg, A., Edqvist, P. H., Ekman, S., Hesselager, G., Ponten, F., Smits, A., Sooman, L., Alafuzoff, I. (2014). Subtyping of gliomas of various WHO grades by the application of immunohistochemistry. Histopathology, 64 (3), 365-379.

Prochazka, L., Tesarik, R., Turanek, J. (2014). Regulation of alternative splicing of CD44 in cancer. Cell Signal., 26 (10), 2234-2239.

Ranuncolo, S. M., Ladeda, V., Specterman, S., Varela, M., Lastiri, J., Morandi, A., Matos, E., Bal de Kier Joffe, E., Puricelli, L., Pallotta, M. G. (2002). CD44 expression in human gliomas. J. Surg. Oncol., 79 (1), 30-35.

Sahlberg, S. H., Spiegelberg, D., Glimelius, B., Stenerlow, B., Nestor, M. (2014). Evaluation of cancer stem cell markers CD133, CD44, CD24: Association with AKT isoforms and radiation resistance in colon cancer cells. PLoS One., 9 (4), e94621.

Shankar, A., Kumar, S., Iskander, A., Varma, N. R. S., Janic, B., deCarvalho, A., Mikkelsen, T., Frank, J. A., Ali, M. M., Knight, R. A., Brown, S., Arbab, A. S. (2014). Subcurative radiation significantly increases cell proliferation, invasion, and migration of primary glioblastoma multiforme in vivo. Chin J. Cancer, 33 (3), 148-158.

Si, D., Yin, F., Peng, J., Zhang, G. (2020). High expression of CD44 predicts a poor prognosis in glioblastomas. Cancer Manag. Res., 12, 769-775.
Sosunov, A. A., Wu, X., Tsankova, N. M., Guilfoyle, E., McKhann, G. M., Goldman, J. E. (2014). Phenotypic heterogeneity and plasticity of isocortical and hippocampal astrocytes in the human brain. J. Neurosci., 34 (6), 2285-2298.

Verhaak, R. G., Hoadley, K. A., Purdom, E., Wang, V., Qi, Y., Wilkerson, M. D., Miller, C. R., Ding, L., Golub, T., Mesirov, J. P. et al. (2010). Integrated genomic analysis identifies clinically relevant subtypes of glioblastoma characterized by abnormalities in PDGFRA, IDH1, EGFR, and NF1. Cancer Cell, 17 (1), 98-110.

Wang, C., Wang, Z., Chen, C., Fu, X., Wang, J., Fei, X., Yan, X., Xu, R. (2020). A small-molecule CD44 dimerizing inhibitor for glioblastoma treatment. Brit. J. Pharmacol., 11 (19), 491-498.

Ward, P. S., Cross, J. R., Lu, C., Weigert, O., Abel-Wahab, O., Levine, R. L., Weinstock, D. M., Sharp, K. A., Thompson, C. B. (2012). Identification of additional IDH mutations associated with oncometabolite R(-)-2-hydroxyglutarate production. Oncogen, 31 (19), 2491-2498.

Xu, H., Tian, Y., Yuan, X., Wu, H., Liu, Q., Pestell, R. G., Wu, K. (2015) The role of CD44 in epithelial-mesenchymal transition and cancer development. OncoTargets Ther., 8, 3783-3792.

Xu, Y., Stamenkovic, I., Yu, Q. (2010). CD44 attenuates activation of the Hippo signaling pathway and is a prime therapeutic target for glioblastoma. Cancer Res., 70 (6), 2455-2464.

Ylagan, L. R., Quinn, B. (1997). CD44 expression in astrocytic tumors. Mod. Pathol., 10 (12), 1239-1246.

\section{CD44 UN IDH1 R132H EKSPRESIJA GLIOMĀS UN TO PROGNOSTISKĀ NOZĪME}

Gliomas ir visbiežākie un agresīvākie primārie centrālās nervu sistēmas audzēji ar sliktu prognozi un ierobežotām ārstēšanas iespējām. Mūsdienās ir daudz pētījumu, kuros pētīti gliomu attīstības molekulārie mehānismi, bet ir atklāts salīdzinoši maz prognostisku markieru. Ir nepieciešams turpināt pētījumus šajā virzienā un identificēt jaunus molekulārus faktorus, kuri varētu būt iesaistīti gliomu izcelsmē vai būtu ar prognostisku nozīmi. CD44 ir viens no perspektīviem molekulāriem markieriem, un tā palielināta ekspresija daudzos audzējos, tai skaitā arī gliomās, ir saistīta ar augstāku invāzijas spēju un sliktāku prognozi. Attiecībā uz gliomām CD44 ir arī aprakstīts arī kā neirālu cilmes šūnu marķieris. Viens no perspektīvākajiem molekulārajiem gliomu marķieriem ir arī IDH1 R132H mutantais proteīns. Mūsdienās IDH1 R132H imūnhistoḳimisku ekspresijas noteikšanu izmanto, lai atškirtu primāras glioblastomas no sekundārām, kurām ir daudz labāka prognoze. Šì pêtījuma mērkis bija izvērtēt CD44 un IDH1 R132H ekspresiju un to prognostisko nozīmi, izmantojot imūnhistokīmiskas vizualizācijas metodi. Retrospektīivā pētījumā tika iekḷauti 146 glioblastomu un 26 difūzu astrocitomu pacienti. Šajā pētījumā konstatēts, ka CD44 ekspresija ir daudz izteiktāka glioblastomās, salīdzinot ar difūzām astrocitomām, un tā nekorelē ar IDH1 R132H ekspresiju. CD44 proteīna ekspresijai netika konstatēta prognostiskā loma, savukārt IDH1 R132H proteīna ekspresijai ir prognostiska nozīme. Intensīvāka CD44 ekspresija biežāk korelē ar mazāku glioblastomas izmēru un sieviešu dzimumu, kas var norādīt uz to, ka gliomu izcelsmē ir iesaistīti arī no dzimuma atkarīgi un ar audzēja augšanu saistīti faktori. 